\section{Comparison of alveohraph and extensigraph properties of winter wheat samples}

\author{
Norbert Boros - Zsuzsanna Tarján - Éva Mars - \\ Mária Borbély - Zoltán Győri \\ Institute of Food Science, Quality Assurance and Microbiology, \\ Faculty of Agronomy, University of Debrecen \\ norbert.boros@hotmail.com
}

\section{SUMMARY}

The rheological properties of dough are determined by the amount and proportion of gliadin and glutenin proteins. Extensibility and resistance to the extension of doughs which can be measured using the extensigraph or alveograph allow good assesment of the baking behavior under realistic conditions. In our study, we compared the extensigraph and alveograph parameters of 87 flour samples. The results showed that the alveograph parameters were different from the extensigraph parameters. The classification of wheat varieties was different, and the order of varieties, as well. The alveograph properties were affected by other factors than the extensigraph properties, except the $W$ value. The two rheological tests did not give similar results, therefor neither test are replaceable.

Keywords: rheological property, alveograph, extensigraph, winter wheat

\section{INTRODUCTION}

The rheological characteristics of dough are determined by the amount and proportion of gliadin and glutenin proteins, and their significance lies in the fact that they affect both the processing ability of the dough and the quality of the end product. The rheological parameters describe the elasticity and viscosity properties of dough samples (Walker and Hazelton, 1996; Faridi, 1985; Faubion and Hoseney, 1990). Several methods are available to measure the rheological characteristics of wheat flour dough (Bloksma and Bushuk, 1988; Benedek and Győri, 1995).

The extensigraph has proved useful in the classification and assessment of flours on the basis of physical dough properties (in particular, flour strength) for both quality control and applied and basic research application. The extensigraph, normally in combination with the farinograph, has been applied in quality control and applications involving flour classification and specification and wheat selection (Rasper and Preston, 1991). More studies have shown significant correlations between extensigraph parameters and bread quality characteristics, mainly on the basis of laboratoryscale baking tests (Campbell et al., 1987; Cressey et al., 1987; Preston et al., 1989).

The alveograph was created by Marcel Chopin based on the idea of Hungarian scientist Jenö Hankóczy in the 1920s (Dubois, 1975; Faridi and Rasper, 1987; Walker and Hazelton, 1996).
It is generally used for the characterization of wheat flours in Southern and Western Europe. The most frequently measured parameters are $\mathrm{W}$ and $\mathrm{P} / \mathrm{L}$ values, and the various flours are classified for bread, baking products, biscuit or pasta making (Matuz et al., 1999; Tóth et al., 2006). The most important alveograph parameter is the $\mathrm{W}$ value, which is proportional to the area under the curve and represents the energy necessary to inflate the dough bubble to the point of rupture (Rasper et al., 1986; Schöggl, 1998).

Extensibility and resistance to the extension of doughs which can be measured using the extensigraph or alveograph allow good assesment of the baking behavior under realistic conditions. These methods have been estabilished globally as AACC and ICC standard methods, respectively.

The aim of the present study is to compare alveograph and extensograph parameters of various winter wheat varieties.

\section{MATERIALS AND METHODS}

Samples are from the Látókép Experimental Site of The University of Debrecen, Centre of Agricultural Sciences. It has calcareous chernozem soil with a 70-90 $\mathrm{cm}$ deep humic layer, the humus content $2.8-3 \%$. The groundwater level is between 6-8 $\mathrm{m}$. This soil has medium level nitrogen and phosphorous and high level potassium supplies. The $\mathrm{pH}$ measured in $\mathrm{KCl}$ is 6.2 . Seven winter wheat varieties were investigated from 2006.

In total, 87 flour samples were analyzed for extesigraph and alveograph properties. Mean flour protein contents of cultivars (GK Öthalom, Saturnus, Lupus, Mv Suba, Mv Magvas, Mv Emese, GK Kalász) were 13.0, 17.2, 15.1, 16.9, 14.5, 16.1, and $15.5 \%$, respectively. The average gluten content of cultivars were very different $(31.3,43.0,37.3,44.2$, $36.8,37.7$ and $37.1 \%$, respectively), as well.

In our study, we determined twelve extensigraph and five alveograph parameters. Dough properties were determined by the Brabender Extensigraph according to Approved Method 54-10 (AACC International 2000). Interpretation of the extensigraph parameters was carried out after 45, 90 and $135 \mathrm{~min}$ of dough maturing. Alveograph parameters were determined according to Approved Method 54-30 (AACC International 2000). The gluten content was determined by Perten Glutomatic. Statistical analysis of the data was performed using SPSS 11.0 statistical software. 


\section{RESULTS AND DISCUSSION}

\section{Classification of winter wheat varieties according to rheological properties}

The Cluster analysis is an appropriate tool for the classification and comparison various wheat varieties. This test is capable of taking all studied parameters in consideraton at the same time. We examined the rheological parameters by hierarchical cluster analysis using Ward method. In the first case, we tested the extensigraph properties of winter wheat varieties (Figure 1). The dendogram showed that four varieties got into one group, and the distance between them was very small. Consequently, these varieties were very similar to each other. Mv Emese was somewhat different from the other varieties. GK Öthalom and GK Kalász belong to the other group, as these varieties were very different from the other examined varieties.

Figure 1: Cluster analysis of wheat varieties by extensigraph properties

Rescaled Distanoe C luster Combine

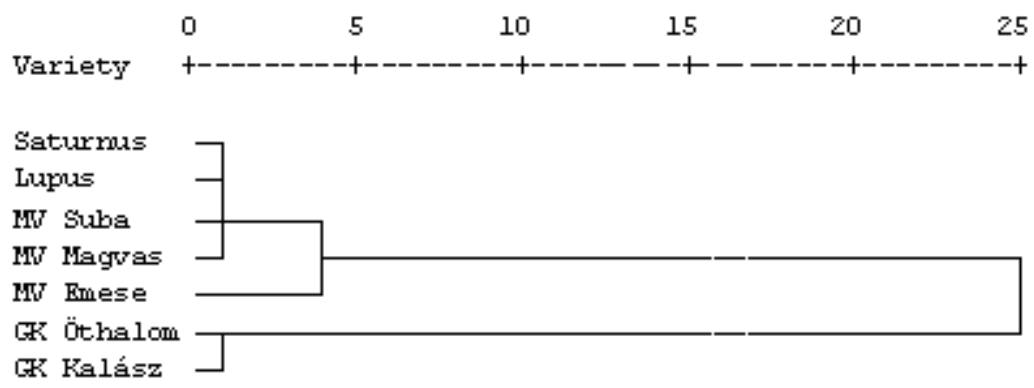

The various varieties got in different groups, when we examined the alveograph properties (Figure 2). Lupus, Mv Suba and Saturnus belong to one group again, but the order was different. Saturnus was the worst variety according to extensigraph parameters, whereas the alveograph properties of this variety were good. GK Kalász with the best extensigraph results and Mv Emese got into the worst group based on alveograph parameters. The two best varieties were GK Öthalom and $\mathrm{Mv}$ Magvas. The distance among the three group was considerable.

Figure 2: Cluster analysis of wheat varieties by alveograph properties

Rescaled Distance Cluster Combine

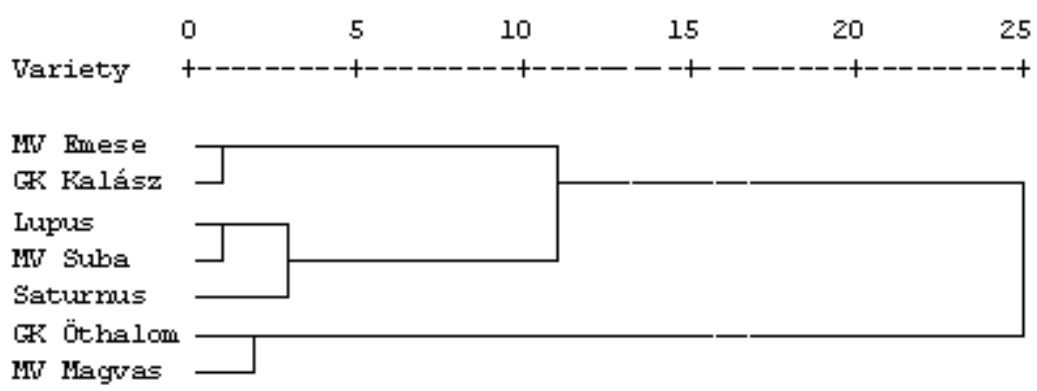

\section{Factors affect the rheological properties}

Factors affecting the rheological properties of dough samples were determined by Principal Component Analysis. Two components determined $93 \%$ of the total variance of extensigraph properties (Table 1). The first component which determined the $66.3 \%$ of the total variance, affected the resistance to extension, the maximum resistance to extension and the area under the curve. The second component affected only the extensibility property of the wheat sample.

When searching for factors which affected the extensigraph and alveograph properties, we found that two components were not enough to explain the $80 \%$ of total variance (Table 2). We needed to include a third component in the investigation. The three components could explain about $90 \%$ of variance of all rheological properties.

The resistance to extension, the maximum resistance to extension and the area under the curve were affected by the first component. The second affected the extensigraph extensibility property as well as the alveograph $\mathrm{W}$ value. The third component affected only the remaining alveograph parameters (P, L, P/L and G) (Table 2). In spite of the fact that extensigraph area and alveograph $\mathrm{W}$ value are very similar properties, extensigraph area property was got into one component with resistance to extension, whereas $\mathrm{W}$ value was got into one component with extensibility, although resistance to extension and extensibility are antagonistic properties. 
Loadings of principal components calculated from extensograph properties

\begin{tabular}{|l|r|r|}
\hline \multirow{2}{*}{ Rheological Property } & \multicolumn{2}{|c|}{ Rotated Component Matrix } \\
\cline { 2 - 3 } & \multicolumn{2}{|c|}{ Component } \\
\cline { 2 - 3 } Area 45 & 1 & 2 \\
Area 90 & $\mathbf{0 . 8 1 9}$ & 0.506 \\
Area 135 & $\mathbf{0 . 8 9 5}$ & 0.384 \\
Resistance to extension 45 & $\mathbf{0 . 9 0 5}$ & 0.311 \\
Resistance to extension 90 & $\mathbf{0 . 9 7 1}$ & 0.052 \\
Resistance to extension 135 & $\mathbf{0 . 9 8 2}$ & -0.009 \\
Extensibility 45 & $\mathbf{0 . 9 6 7}$ & -0.007 \\
Extensibility 90 & 0.096 & $\mathbf{0 . 9 4 5}$ \\
Extensibility 135 & 0.071 & $\mathbf{0 . 9 4 8}$ \\
Maximum resistance 45 & 0.129 & $\mathbf{0 . 9 1 3}$ \\
Maximum resistance 90 & $\mathbf{0 . 9 4 9}$ & 0.225 \\
Maximum resistance 135 & $\mathbf{0 . 9 7 8}$ & 0.115 \\
\hline Extraction Sums of Squared Loadings & $\mathbf{0 . 9 7 1}$ & 0.047 \\
\hline Total & & \\
\% of Variance & & 3.961 \\
Cumulative \% & 66.346 & 26.642 \\
\hline
\end{tabular}

Extraction Method: Principal Component Analysis, 2 components extracted

Rotation Method: Varimax with Kaiser Normalization

Bold data are significant

Loadings of principal components calculated from the extensigraph and alveographic properties

\begin{tabular}{|c|c|c|c|}
\hline \multirow{3}{*}{ Rheological Property } & \multicolumn{3}{|c|}{ Rotated Component Matrix } \\
\hline & \multicolumn{3}{|c|}{ Component } \\
\hline & 1 & 2 & 3 \\
\hline Area 45 & 0.843 & 0.467 & 0.060 \\
\hline Area 90 & 0.922 & 0.313 & 0.009 \\
\hline Area 135 & 0.927 & 0.237 & 0.022 \\
\hline Resistance to extension 45 & 0.959 & 0.021 & 0.124 \\
\hline Resistance to extension 90 & 0.971 & -0.056 & 0.116 \\
\hline Resistance to extension 135 & 0.957 & -0.121 & 0.076 \\
\hline Extensibility 45 & 0.168 & 0.907 & -0.010 \\
\hline Extensibility 90 & 0.159 & 0.876 & $-0,216$ \\
\hline Extensibility 135 & 0.212 & 0.825 & -0.112 \\
\hline Maximum resistance 45 & 0.951 & 0.189 & 0,094 \\
\hline Maximum resistance 90 & 0.979 & 0.062 & 0.072 \\
\hline Maximum resistance 135 & 0.970 & -0.013 & 0.053 \\
\hline 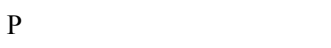 & -0.089 & 0.399 & 0.867 \\
\hline $\mathrm{L}$ & -0.219 & 0.336 & -0.871 \\
\hline $\mathrm{P} / \mathrm{L}$ & 0.079 & 0.001 & 0.986 \\
\hline G & 0.201 & 0.318 & -0.890 \\
\hline $\mathrm{W}$ & -0.068 & 0.766 & 0.145 \\
\hline \multicolumn{4}{|c|}{ Extraction Sums of Squared Loadings } \\
\hline Total & 8.208 & 3.661 & 3.421 \\
\hline$\%$ of Variance & 48.281 & 21.533 & 20.126 \\
\hline Cumulative $\%$ & 48.281 & 69.815 & 89.941 \\
\hline
\end{tabular}

Extraction Method: Principal Component Analysis, 3 components extracted

Rotation Method: Varimax with Kaiser Normalization

Bold data are significant

\section{CONCLUSIONS}

The measurement of dough stretching properties is one of the most important techniques used to evaluate flour quality for baking. In our study we compared the results of two rheological tests.
The classification of wheat varieties was different, and the order of varieties, as well. The results showed that the alveograph parameters were different from the extensigraph parameters. The alveograph properties were affected by other factors than the 
extensigraph properties, except the $\mathrm{W}$ value, which was affected by the second factor.

A considerable proportion (93\%) of the total variance of extensigraph properties was determined by two components. When studying the extensigraph and alveograph parameters at same time, we needed to include the third component in the investigation. The three components could explain about $90 \%$ of variance of all rheological properties. The two rheological tests did not give similar results, therefor neither test are replaceable. The data presented are for a set of cultivars grown at one location and in one year, it could be very interesting to continue these examinations on different cropping years and sites.

\section{REFERENCES}

Benedek Á.-Győri Z. (1995): A különböző termőhelyen termesztett búzafajták lisztminőségi paramétereinek összehasonlítása. Növénytermelés, 44. 11-17.

Bloksma, A. H.-Bushuk, W. (1988): Rheology and chemistry of dough (3rd ed. In Y. Pomeranz (Ed.). Wheat chemistry and technology (vol. II). St. Paul, Minnesota, USA: American Association of Cereal Chemists. 131-217.

Campbell, W. P.-Wrigley, C. W.-Cressey, P. J.-Slack, C. R. (1987): Statistical correlations between quality attributes and grain protein composition for 71 hexaploid wheats used as breedung parents. Cereal Chemistry, 64, 293-299.

Cressey, P. J.-Campbell, W. P.-Wrigley, C. W.-Griffin, W. B. (1987): Statistical correlations between quality attributes and grain protein composition for 60 advanced lines of crossbred wheat. Cereal Chemistry, 64, 299-301.

Dubois, M. (1975): Backfanhigskeitsuntersuchungen an Franzosischen Weizen in der Letzten 30 Jahren. Getreide Mehl und Brot. 29. 5. 141-144.

Faridi, H. (1985): Rheology of Wheat Products. American Association of Cereal Chemists, St. Paul, MN

Faridi, H.-Rasper, V. F. (1987): The Alveograph Handbook, AACC, St. Paul, Minnesota, USA

Faubion, J. M.-Hoseney, R. C. (ed.: Faridi, H.-Faubion, J. M.) (1990): The viscoelastic properties of wheat flour doughs. In:
Dough Rheology and Baked Product Texture. Van Nostrand Reinhold, New York

Matuz J.-Markovics E.-Ács E.-Véha A. (1999): Öszi búzafajták lisztjének minőségi tulajdonságai közötti összefüggések vizsgálata. Növénytermelés, 48. 243-254.

Preston, K. R.-Tripples, K. H.-Morgan, B. C. (1989): Prediction of milling and baking characteristics of Canadian wheat. Pages 505-518. In ICC '89 Symposium-Wheat End-Use Properties. H. Salovaara, ed. Univ. Helsinki

Rasper, V. F.-Preston, K. R. (1991): The Extensigraph Handbook, AACC, St. Paul, Minnesota, USA

Rasper, V. F.-Pico, M. L.-Fulcher, R. G. (1986): Alveography in quality assessment of soft white winter wheat cultivars. Cereal Chemistry, 63, 359-400.

Schöggl, G. (1998): Überprüfung der technologischen Aussagefähigkeit von Alveogrammwerten zur Weizenbeurteilung. Getreide Mehl und Brot, 52, 218-223.

Tóth Á.-Sipos P.-Győri Z. (2006): A GK Öthalom és a Fatima őszi búzafajták (Triticum aestivum) alveográfos minőségének alakulása az évjárat és különös tekintettel a mütrágyázás hatására, nyolc év eredményei alapján. Növénytermelés. 55: $15-26$

Walker, C. E.-Hazelton, J. L. (1996): Dough Rheological Tests. Cereal Foods World, 41. 1. 23-28. 